\title{
E-Reading in Organizations: Users' Satisfaction and Preference
}

\author{
NORSHUHADA SHIRATUDDIN \\ SHAHIZAN HASSAN \\ Faculty of Information Technology \\ Universiti Utara Malaysia
}

\begin{abstract}
This paper defines electronic reading (e-reading) and then continues to discuss the diverse definitions of the main resource of e-reading, which are, electronic books (e-books). It then proceeds to describe the formats and standards of existing e-book initiatives, which are gaining wider interest since the introduction of portable electronic reading devices and software-based readers that provide users with a more realistic book reading experience. Advantages, disadvantages, and problems with paper-based reading are also explained. In addition, a study concerning an evaluation of e-reading satisfaction is described. Three different e-book formats (LIT, PDF, and HTML) were utilised to accomplish the primary aims of the study, which were to identify the most preferred format, associated software-based reader (Microsoft Reader, Adobe Acrobat Reader, Internet Explorer), and the potential of e-reading in the workplace. Based on a proposed preferred index, the results seem to suggest that Microsoft Reader is more preferable when compared to the other two. However, most participants preferred reading on paper rather than on screen. Although this was the case, some participants would e-read depending on resources and situations.
\end{abstract}

\footnotetext{
ABSTRAK

Artikel ini mendefinisikan pembacaan secara elektronik (e-pembacaan) dan kemudian diteruskan dengan perbincangan pelbagai definisi sumber utama e-pembacaan iaitu buku elektronik (e-buku). Seterusnya, diikuti pula dengan penerangan tentang format dan piawaian initiatife-buku terkini yang sedang diminati ramai sejak pengenalan alat-alat e-pembacaan mudah alih yang menyediakan pengalaman pembacaan realistik kepada pengguna. Kebaikan, keburukan, dan masalah-masalah pembacaan berasaskan kertas juga diterangkan. Selain itu, satu kajian tentang penilaian kepuasan e-pembacaan turut dijelaskan. Tiga format e-buku yang berbeza (LIT, PDF, dan HTML) digunakan untuk mencapai matlamat utama kajian iaitu mengenal pasti format dan pembaca berasaskan perisian (Microsoft Reader, Adobe Acrobat Reader, Internet Explorer) yang menjadi pilihan dan potensi untuk e-pembacaan di tempat kerja. Berdasarkan satu indeks pilihan yang dicadangkan, keputusan menunjukkan bahawa Microsoft Reader lebih disukai berbanding dengan dua yang lain. Bagaimanapun, kebanyakan peserta memilih pembacaan melalui kertas berbanding dengan skrin. Walaupun begitu, sebilangan peserta akan melakukan epembacaan bergantung kepada sumber dan keadaan.
} 


\section{INTRODUCTION}

Reading is considered as a basic learning activity (Cavanaugh, 2002). A person might read a book for entertainment (e.g. to self-inform) or for inspiration (e.g. to learn or to prepare for a discussion) (Schilit, 1999). With the wide availability of electronic content, which can be distributed through Web sites, electronic mail (email), and the Internet, reading is now extended to electronic reading (e-reading), which has been globally accepted (Faber, 1999) in many organizations. From managerial to clerical level staff, whether they realise it or not, have experienced e-reading, which refers to reading texts or other types of information using a computer screen. The success of this activity depends on the readability of the text and the presentation of the other types of information.

Normally, the term readability is taken to mean "all factors that affect success in reading and understanding text" (Johnson, 1998). Generally, researchers measure the readability through comprehension tasks and reading speed (SHORE, 2000) ${ }^{1}$. However, several studies measure readability by font types and sizes. For example, a study related to text font readability found that most individuals prefer Sans Serif fonts as compared to Serif fonts (Wilson, 2001). In this article, readability is measured by factors that contribute to e-reading satisfaction.

An electronic book (e-book) is the most common e-reading resource and the term itself has several interpretations. Initially paper books that had been converted to a digital format (usually through a digitising process, which allowed them to be displayed on computers) were defined as ebooks (that is, paperless version of a book, report, and manual). The term also encompassed multimedia, hypertext or hypermedia systems that are based on a book metaphor. Now, the definition of an e-book has been extended to include book titles that are available on-line, can be read as emails, can be retrieved by a portable electronic reading device, as a file that can be downloaded onto a computer or can be printed-on-demand (Carvajal, 1999; Clister, 1999; Allen, 2000; Hawkins, 2000a).
Open eBook (OEB) Forum avoids using the e-book term since different people use the term differently; so they define a more precise terminology: the digital content which users read is called a publication; the physical device used to read a publication is called a reading device (e.g. dedicated readers, personal computers, or personal digital assistants (PDAs)). In addition to e-book reading devices, general-purpose softwarebased readers have also been developed which are used on personal computers or laptops. They function in a similar way to dedicated readers but no special hardware is required. Microsoft Reader and Adobe Acrobat Reader are examples of such software; and the combination of software and hardware that processes the content and presents it to the users is called a reading system.

\section{Formats}

E-books are available in a wide range of formats, the simplest of which is plain ASCII-standard text. However, this format is extremely unappealing to read, cannot preserve formatting or handle graphics. To solve these problems, the following formats can be used (Armstrong \& Lonsdale, 1998; Allen, 2000; Hawkins, 2000a):

\section{- Adobe Acrobat's PDF, ${ }^{2}$}

- $\quad$ Adobe Acrobat eBook (PDF-based);

- $\quad$ Microsoft Reader's Literature (LIT) ${ }^{3}$

- Software for PDAs (e.g. Palm Doc, Mobipocket, Gemstar, and Hiebook);

- $\quad$ Markup languages (e.g. HyperText Markup Language - HTML, Standard Generalised Markup Language - SGML, eXtensible Markup Language - XML);

- Instant e-book;

- $\quad$ Plain text;

- Microsoft Word.

The most popular formats according to Hitchcock, Carr and Hall (1997) are either HTML or PDF. Although their study is now rather outdated, in general the findings still hold as reported in Norshuhada, Landoni, Gibb and Shahizan (2003a), the dominant formats encountered in existing e-books are the formats mentioned earlier. However, this may soon change as the LIT format is becoming widely used. 


\section{Standards}

The OEB Forum ${ }^{4}$ recently released the Open eBook Publication Structure Specification (OEBPS) 1.0.1. It is the new industry standard and is an XML-based specification for the content, structure, and presentation of e-books. It provides a single common format for authors, editors, publishers, and content owners who want their titles to be readable by a variety of electronic publishing (e-publishing) systems and reading devices (Thomson Multimedia, 2000; Hawkins, 2000b).

Whatever definition that is adopted or the format employed, it is wise to consider the advantages and disadvantages of the technology before embracing it to avoid incorrect decisions. The initial section of this paper discusses the issues. Then the methodology and results of the potential of e-reading in the workplace are presented. The main focus of the study is on measuring users' satisfaction of e-reading when utilising different e-book formats with different software-based readers.

\section{ADVANTAGES AND DISADVANTAGES OF ELECTRONIC CONTENT}

Are there compelling reasons why content should be in electronic form? To answer this, it is necessary to identify the advantages and disadvantages of printed and electronic content. According to Bonime and Pohlmann (1998), electronic content benefits from hyper links (contents can be linked to other pages inside and outside the book), non-linearity (i.e. the order of access can be determined by users), addition of multimedia (i.e. content presentation is enhanced by mixing multiple information types such as images, sound, and video), data density (storage capacity is decreased while at the same time increasing portability), and searching (the usefulness of the content is enhanced by the ability of the users to locate any piece of information, or to access any section instantly). A comparison of the features of paper based books and e-books provided by Rawlins (1991) and Bonime and Pohlmann (1998) can be used as a guideline when considering the possibility of converting printed information to electronic form. Additionally, findings by Espinosa and Chen (2001), McCreary, Ehrich and Lisanti (2001), Norshuhada (2001; 2002), Shields and Behram (2000), Seniuk (2001), Norshuhada and Landoni (2002; 2003), and Norshuhada, Shahizan and Landoni (2003b) can assist in the decision-making.

Nonetheless, it should be noted that not everyone agrees with the real impact of these technologies in the workplace. A number of comprehensive reviews have concluded that excessive, unmonitored use of computers and other screen technologies can place users at risk for harmful effects on their physical (e.g. eyes, back and wrists), social, and psychological development (Marriott \& Stuchly, 1986; MacKay, 1989).

\section{Problems of Paper-Based Reading}

Currently, in many organizations, the traditional paper based books, reports, manuals, official letters, or articles are the main on-the-job reading resources. Several issues limit the usefulness of these printed contents and these are discussed.

The fixed text style and size can be a limitation for paper based books (Fatrah \& Norshuhada, 2003). The Times New Roman font style with size 12 is the most common printed font standard. Once it has been printed, the font style and size cannot be changed. For some readers, this size is too small to read comfortably. Fortunately, e-reading allows the font size to be enlarged or its font type changed, making reading less tiring (Schilit, 1999).

Annotations such as highlighting or adding bookmarks are among normal reading activities. According to Hawkins (2000b), for paper based books, annotations may damage the books. However e-reading allows a person to highlight the key information and add bookmarks easily without damaging the physical page appearance or the book.

Printed materials do not offer a navigation bar, which can provide instant page location. Individuals need to manually flip the sheets to move to a selected topic or content. Electronic content, on the other hand, offers automatic navigation where a user can move to selected topic by only clicking the table of contents 
or navigation bar. Moreover, to search for certain keywords, one needs to find it in the index first before moving to that particular page (Fatrah \& Norshuhada, 2003). These processes are tedious and time consuming as compared to e-reading which provides a search tool and returns immediate results.

In addition, paper based books do not provide multimedia elements that can make the reading activity more interactive and easy to be understood. It only presents two-dimensional static pictures that cannot be explored by users (Fatrah \& Norshuhada, 2003). In contrast, contents of e-books can be read aloud by the software-based readers, which is a highly useful feature for the disabled.

Schilit (1999) states that other limitations of paper based book are price, storage space, and weight. In the workplace, a considerable amount of the operating budget is allocated for buying paper, ink, and photocopying materials. The price of paper based books is usually more expensive compared to e-books, as the selling price would include the cost of printing, royalties, distribution, retailing, and retail returns. Printed books also require a bigger storage space. The weight of 10 paper books is huge compared to 10 e-books (Selvidge \& Philips, 2002).

With all the above problems and disadvantages associated with printed books, this research examines issues regarding the satisfaction of users with e-reading, particularly in the workplace, and its associated technology.

\section{E-Book Reading Methods}

According to Matt (2000), there are three ways of reading an e-book; that is reading on PDA, reading on desktop or laptop computers, and reading on a specialised and dedicated e-book device, for example the Softbook Reader (Fatrah \& Norshuhada, 2003). In this study, due to the prohibitive cost of financing special devices, only e-reading on the desktops and laptops were investigated as these are readily and easily accessible.

E-reading on the desktop or laptop computer is performed using software-based readers, which is an alternative way to accessing an e-book rather than using a specialised e-book device. Software-based readers are programs that can be activated in a desktop, laptop, or pocket personal computer (PC) device (Dearnley \& McKnight, 2001). Common examples are Microsoft Reader, Adobe Acrobat Reader, Adobe Acrobat Professional, and Internet Explorer. Compared to e-book devices, software-based readers can be freely downloaded from the Internet (The United Methodist Publishing House, 2003).

ClearType technology in Microsoft Reader allows words on the screen to appear close to the quality of fonts in a printed book. Smart navigation system that remembers previous pages read and flexibility of font sizes and styles are among the features included. Microsoft Reader also creates an annotation file that allows highlighting, drawing, note taking, and interactive dictionaries (Fatrah \& Norshuhada, 2003). It also has a search feature that allows specific word or sentences to be found instantly (Cavanaugh, 2002). Text-to-speech is another technology provided by Microsoft Reader allowing the ebook, which is in the LIT format, to be read-aloud to users (eBookMall, Inc., 2003).

Adobe Acrobat Reader is the most common software used to display articles or journals in PDF format (Fatrah \& Norshuhada, 2003). Its' files preserve the fonts, formatting, graphics, and colour of any source document that can also be shared, viewed, navigated, and printed. The files can be attached to e-mails, saved on corporate servers, posted on Web sites, or on Compact Disc-Read Only Memory (CD-ROM) (eBookMall, Inc., 2003). Adobe Acrobat Professional 6.0, the latest e-book reader offers all features that exist in its predecessor (Adobe Acrobat eBook Reader). CoolType technology is utilised to improve on-screen text resolutions for better readability on a liquid crystal display (LCD) screen. Similarly to Microsoft Reader, it also offers annotation, search features, and navigation (eBookMall, Inc., 2003).

In addition to these specific softwarebased readers, browsers such as Internet Explorer, which is commonly installed in Windows PCs or Windows tablet, are also able to present e-books in markup language format. It provides hypertext 
navigation that allows users to move to another page by clicking on the selected words or sentences. No special devices are required to read the e-book and font settings used in the browser can be changed to suit users' preferences (eBookMall, Inc., 2003).

\section{MEASURING USER SATISFACTION}

The objective of evaluating user satisfaction is to discover what users think and feel about a proposed concept or in using a product. Commonly, an evaluation has three goals, which are to compare, evaluate quality, and seek the weaknesses of a particular concept or product. It can be performed by asking people to share their experiences and opinions. The opinion-based evaluation method is a technique that aims to observe users' opinions, through questionnaires, interviews, and surveys.

A study that focused on reading e-books on the three software-based readers (i.e. Microsoft Reader, Adobe Acrobat Professional, and Internet Explorer) was conducted. The respondents came from managerial to support level staff from educational, governmental, banking, and business organizations. The objectives of this study are:

1. to evaluate workers' satisfaction on reading an e-report in three different formats (LIT, PDF and HTML) with three different software-based readers;

2. to identify the most preferred softwarebased reader; and

3. to report the potential implementation of e-reading in the workplace.

\section{METHODOLOGY}

To achieve the objectives, the following activities were conducted:

\section{Preparation of an e-Report in All Formats}

The 2000 annual report by UNICEF (United Nations Children's Fund) in PDF format was acquired (UNICEF, 2001). Based on this PDF file, the LIT format was produced. Meanwhile, the HTML format version was developed to follow the conceptual models as suggested in Morkes and Nielson's (1997) and Norshuhada (2002), scannable guidelines.

\section{Construction of Instrument and Test Tasks}

A questionnaire that explores opinion, preference, experience, areas of difficulties, and suggestions for improvement was utilised as an instrument to compare these software. The questionnaire was modified from a previous study related to evaluating users' satisfaction (SHORE, 2000) and it consisted of two parts; the respondents' background and the measurement of users' satisfaction on reading the e-report. A five-point Likert scale was adopted and the instrument was made available in an electronic form.

Test tasks were constructed and distributed with the questionnaire. The tasks consisted of 13 instructions (see Figure 1) that were performed by the respondents when reading the e-report. The purpose of the tasks was to encourage the users to utilize all the possible features that are available for each software-based reader (Fatrah \& Norshuhada, 2003). In addition, the aim of the tasks was to serve as a guideline for the users as to what they should do and what features (e.g. font changing, highlighting, bookmarking, and note-taking) they could use in their e-reading activities.

\section{Data Collection and Analysis}

Within a period of about four months, there were 32 respondents. They were asked to download all of the three software-based readers and the different formats of the e-report. Figure 2 depicts the PDF version and the features available in Acrobat Professional. When ready, the respondents were reminded to record learning time, complete the tasks, and answer the on-line questionnaire. Respondents were asked on overall satisfaction (OS), ease of use (EU) for each of the softwarebased reader, time taken to learn on how to operate the readers (TL), and their views on the features provided by each reader (AF). 


\section{TASKS}

Please read these instructions and perform these tasks before completing the questionnaire.

1. Double click on "UNICEF annual report. html" file.

2. Click on "Section 2" to read the passage.

3. Change the font size and type, according to your preferences (if this function is not available, proceed to the next task).

4. Click on the play button to allow the software-based reader to read aloud for you, and click the stop button to stop reading (if this function is not available, proceed to the next task).

5. Click on "scrolling automatically" menu to allow the pages to move up automatically (if this function is not available, proceed to the next task).

6. Rotate the page you are reading to landscape layout (if this function is not available, proceed to the next task). Continue reading the page.

7. Highlight the word "children" in section 2 (if this function is not available, proceed to the next task).

8. Go to page 4 and circle the first paragraph (if this function is not available, proceed to the next task).

9. Add the following notes on the same page (if this function is not available, proceed to the next task): "Children deserve more help"

10. Add a bookmark on page 4 and change the bookmark colour to your preferences (if this function is not available, proceed to the next task).

11. From page 4, go to page 6 then the last page.

12. Search using keyword "children". Note the page numbers.

13. Repeat step 1 to 12 using Microsoft Reader (UNICEF annual report. lit) and Adobe Acrobat Reader (UNICEF annual report. pdf).

\section{Figure 1}

Tasks performed by respondents.

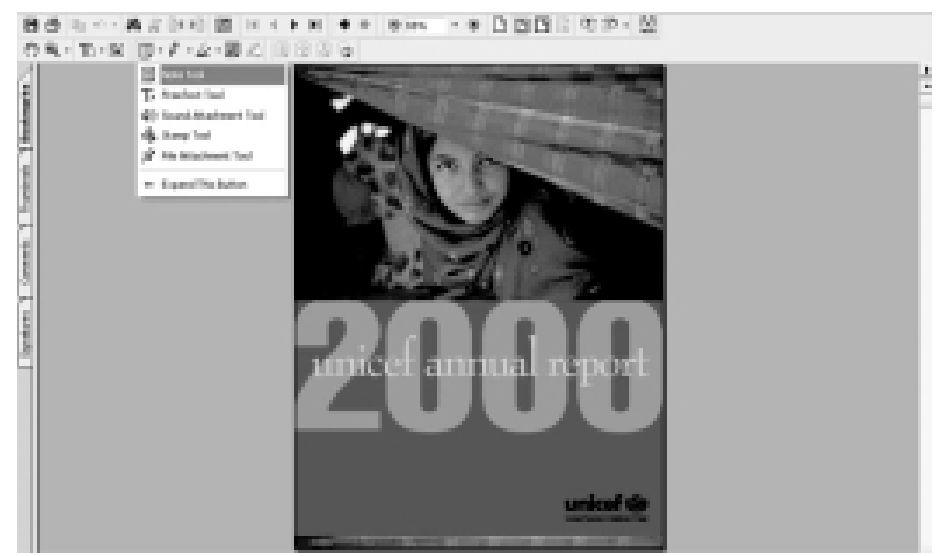

Figure 2

PDF version of the annual report. 


\section{FINDINGS}

Most of the respondents (37\%) were from educational organizations (see Figure 3). Their responsibilities in the organizations can be organised into 12 categories as depicted in Figure 4. About 55 percent of them spent more than 20 hours per week using the computer and another 35 percent used the computer from 10 to 20 hours weekly. Only a mere 10 percent utilised the computer less than 5 hours per week. In addition, about 97 percent of the respondents had never used Microsoft Reader before.

The respondents $(86 \%)$ were generally satisfied with the Microsoft Reader. Although, only about a quarter of the respondents were satisfied with the Internet Explorer, it was considered as the easiest software-based reader to use (nearly $82 \%$ respondents found Internet Explorer was easy to use). This may be due to

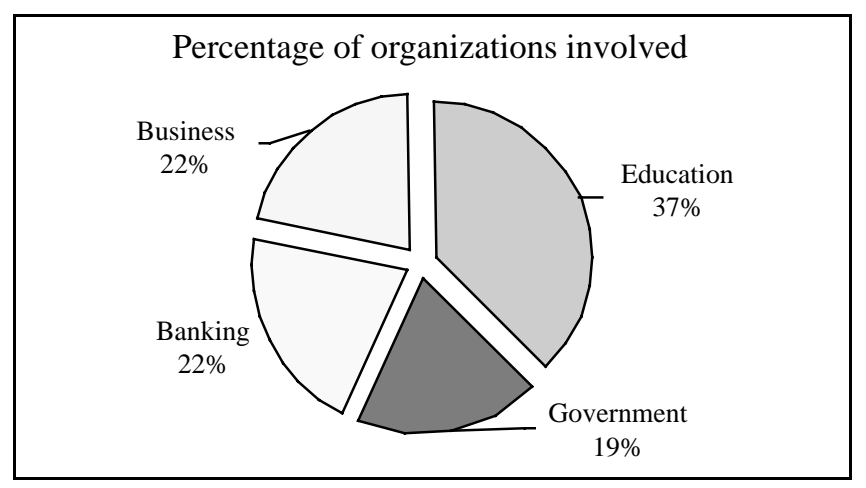

Figure 3

Types of organizations.

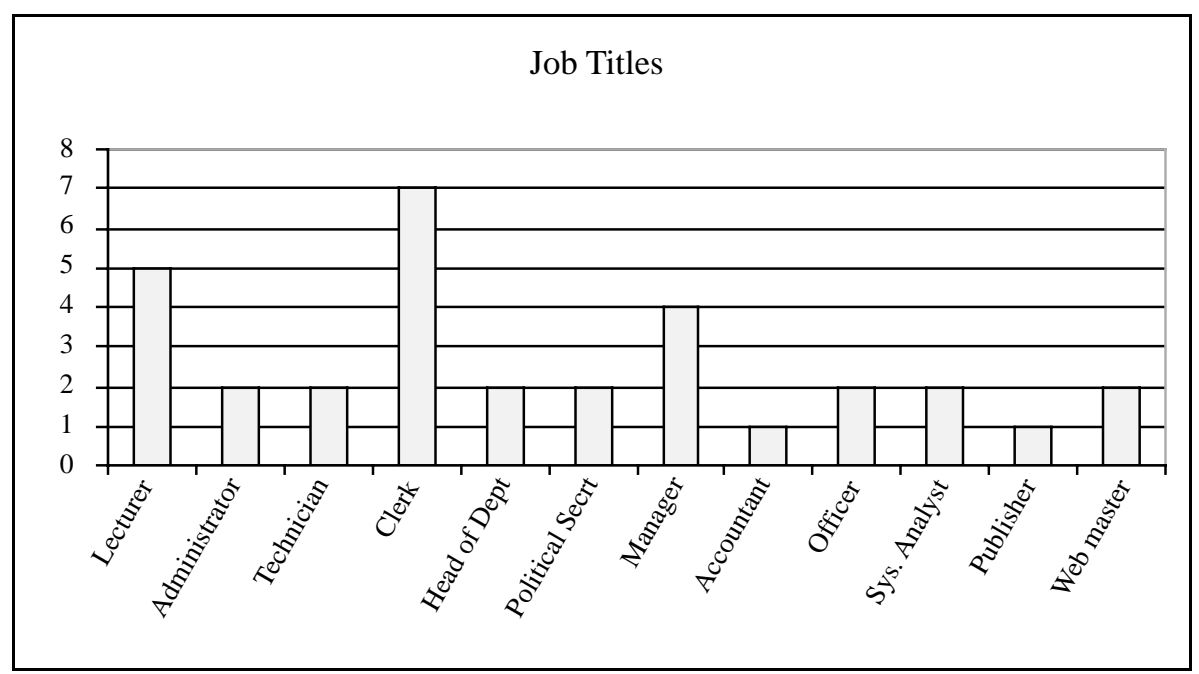

Figure 4

Respondents' job titles. 
their previous experience with the browser (all of them had prior experiences with it).

Roughly 52 percent of the respondents were unsure about the ease of use of the Adobe Acrobat software reader. This is followed by Microsoft Reader (41\%), and the Internet Explorer (16\%). No respondent believed that Microsoft Reader was difficult and just one said Adobe Acrobat was difficult. These results seem to suggest that although a number of respondents were unsure about the ease of use of all readers, many were able to learn after some time.

On average, the respondents took 23.38 , 19.55, and 10.88 minutes to learn how to use Microsoft Reader, Adobe Acrobat Reader Professional, and Internet Explorer respectively (see Figure 5). Learning the Internet Explorer was the fastest. Again, this may be due to their previous experience and also the lack of features to explore while e-reading.

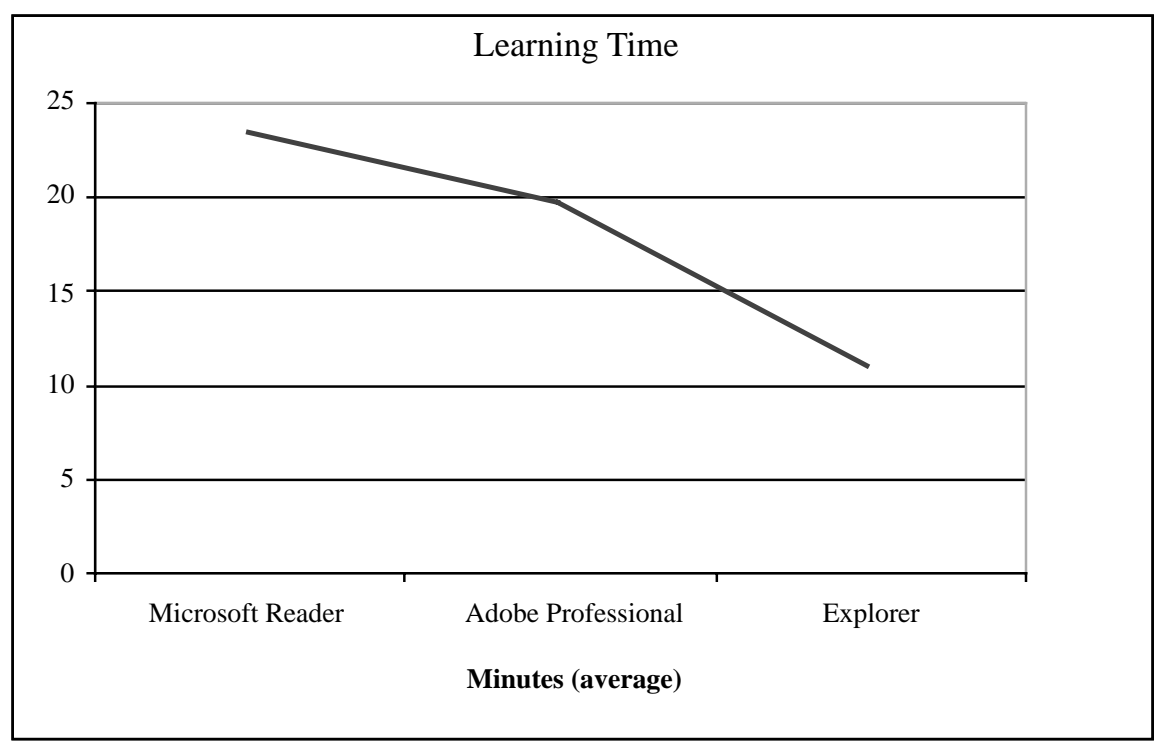

Figure 5

Average learning time.

Microsoft Reader provides the most features for reading an e-book when compared to the other software-based readers. This was evident when approximately 92 percent of the respondents said the reader provided adequate features such as highlighting, book marking, hyper linking, and note taking. Many respondents responded that the Internet Explorer did not provide adequate features. For Acrobat Reader, only about 15 percent of the respondents were dissatisfied with the features. Meanwhile, no respondent found Microsoft Reader's features as inadequate.

The reason why many respondents felt that the Internet Explorer provided inadequate features may be contributed to the main function of the software. It is obvious that the software was not specifically designed for reading electronic contents, hence the lack of many e-reading features.

\section{Most Preferred Software-based Readers}

The most preferred index was formed by adding group means for each software for OS, EU, and AF. A high value for the total of all these means represents the more preferable the software-based reader. Therefore, the formula for the preferred format $(\mathrm{PF})$ is constructed as follows: 
where:

$\mathrm{PF}=\overline{\mathrm{X}}_{\mathrm{OS}}+\overline{\mathrm{X}}_{\mathrm{EU}}+\overline{\mathrm{X}}_{\mathrm{AF}}$

$\bar{X}_{\mathrm{OS}} \quad=$ mean value for overall satisfaction

$\overline{\mathrm{X}}_{\mathrm{EU}} \quad=$ mean value for ease of use of each software-based readers

$\overline{\mathrm{X}}_{\mathrm{AF}}=$ mean value for features provided by each software-based readers

From Table 1, it is found that most of the respondents preferred Microsoft Reader. A further analysis to compare the significant difference between these values was carried out. Assuming the null hypothesis, the result of an ANOVA statistical test revealed that, the probability (p) was $0.330(\mathrm{~F}=1.34)$, which indicates no significant difference was found between these three values.

The potential for e-reading in the workplace was also discussed and it was found that most respondents $(78.8 \%)$ still prefer paperbased reading. Although this was the case, a majority of them were not against e-reading and would participate in the activity depending on several factors. For instance, if there is no access

\section{Table 1}

The Group of Mean Values for Each Software-Based Reader.

\begin{tabular}{cccc}
\hline & $\begin{array}{c}\text { Microsoft Reader } \\
\text { (LIT format) }\end{array}$ & $\begin{array}{c}\text { Adobe Acrobat } \\
\text { (PDF format) }\end{array}$ & $\begin{array}{c}\text { Internet Explorer } \\
\text { (HTML format) }\end{array}$ \\
\hline$\overline{\mathrm{X}}_{\mathrm{OS}}$ & 4.41 & 3.55 & 3.02 \\
$\overline{\mathrm{X}}_{\mathrm{EU}}$ & 3.84 & 3.32 & 4.75 \\
$\overline{\mathrm{X}}_{\mathrm{AF}}$ & 4.58 & 3.42 & 2.28 \\
$\mathrm{PF}$ & 12.83 & 10.29 & 10.05 \\
\hline
\end{tabular}

to printers or when they are required to make copies of reports or manuals for themselves in the workplace.

Respondents were also asked as to which e-book reader features were considered useful. Bookmarking, note-taking, highlighting, searching, hyper linking, and menu navigating were considered as the most useful features.

\section{CONCLUSION}

The possibility of introducing electronic content into the workplace was investigated. Three e-book reading software were utilised to find the users' level of satisfaction. In addition, the most preferred index was formed. Generally, the results seem to indicate that Microsoft Reader was the most preferred environment, but respondents still prefer reading on paper rather than on screen. Although this was the case, organizations should not regard it as a negative viewpoint. Implementing e-reading in the workplace could reduce administrative operating costs including the cost for paper and ink. Moreover, a majority of the respondents stated that they did not disregard e-reading totally and would do so depending on situations they encountered.

Many organizations are already utilising electronic content in the form of memos, announcements, electronic bulletins, and official letters through e-mails. Extending this practice to 
include reports, manuals, and other documents is seen as the next appropriate administrative strategy, which supports the use of Information and Communication Technology (ICT) in the workplace.

\section{ENDNOTES}

1 Student HCI Online Research Experiments (SHORE), conducted under the Department of Computer Science, University of Maryland, USA.

2 Go to http://www.adobe.com/products/acrobat/ readermain.html

3 Go to http://www.microsoft.com/reader/ default.asp

${ }^{4}$ Go to http://www.openebook.org

\section{REFERENCES}

Allen, M. (2000). E-publishing FAQ, Inkspot. Retrieved Oct 24, 2000, from http:// www.inkspot.com/epublish/ articles/ epublishfaq.html.

Armstrong, C., \& Lonsdale, R. (1998). The publishing of electronic scholarly monographs and textbooks, Aberystwyth: University of Wales.

Bonime, A., \& Pohlmann, C. (1998). Writing for new media: The essential guide to writing for interactive media, CD-ROMS and the Web, New York: John Wiley \& Sons.

Carvajal, D. (1999). Racing to convert books to bytes, The New York Times.

Carvajal, D. (2000). Digital publishing: from Arthur C. Clarke to Psoriasis tales, The New York Times, , Feb 7.

Cavanaugh, T. (2002). Ebooks and accommodations: Is this the future of print accommodation? TEACHING
Exceptional Children, 35(2). Retrieved May 11,2003, from http://search.epnet.com/ direct.asp?an=EJ655584\&db=eric\&tg=AN.

Clister, J. (1999). Electronic books, Conference on Human Factors in Computing Systems, CHI99 Workshop: Designing Electronic Books. ACM. Retrieved June 11, 2001, from http://www.fxpal.com/ ConferencesWorkshops/chi99deb/ submissions/clister.htm.

Dearnley, J., \& McKnight, C. (2001). The revolution starts next week: The findings of two studies considering electronic books. Journal of Information Services \& Use, 21(2). Retrieved May 11, 2003, from http://search.epnet. com/ direct.asp? $\mathrm{an}=5847810 \& \mathrm{db}=\mathrm{afh}$.

eBookMall, Inc. (2003). About ebook. Retrieved May 9, 2003, from http:// w w w. e b o o k m a 11 . c o m/ aboutebooks.htm\#top.

Espinosa, L. M., \& Chen, W. J. (2001). The role of technology in supporting multiage classroom practices, Information Technology in Childhood Education Annual, AACE, 5-32.

Faber, R. (1999). Computers flunk electronic reading test. Electronic Engineering Times, 1092. Retrieved May 11, 2003, from http://search.epnet.com/ direct.asp? $\mathrm{an}=2638969 \mathrm{db}=\mathrm{afh}$.

Fatrah, W. E., \& Norshuhada, S. (2003). Ereading: Evaluating users' satisfaction on electronic content formats, Proceedings of Masters Seminar-Sept, Faculty of Information Technology, Universiti Utara Malaysia.

Hawkins, D. (2000a). Electronic books: A major publishing revolution, Part 1, Online, 1528. 
Hawkins, D. (2000b). Electronic books: A major publishing revolution, Part 2, Online, 1935 .

Hithcock, S., Carr, L., \& Hall, W. (1997). Web journals publishing: A UK perspective. Serials, 10(3). Retrieved May 11, 2003, from http://journals.esc.soton .ac.uk/ uksg.htm.

Johnson, K. (1998). Readability. Retrieved August, 17, 2003, from http:// www.timetabler.com/readable.pdf.

MacKay, C. (1989).Work with visual display terminals: Psychosocial aspects and health, Journal of Occupational Health. 31, 957-968.

Marriott, I., \& M. Stuchly. (1986). Health aspects of work with visual display terminals, Journal of Occupational Health . 28, 833-848.

Matt, R. (2000). Borders.com provides three choices on downloading e-books, Crain's Detroit Business 16(9). Retrieved May 11, 2003, from http://search.epnet.com/ direct.asp? $\mathrm{an}=2860268 \& \mathrm{db}=\mathrm{bwh}$.

McCreary, F., Ehrich, R. W., \& Lisanti, M. (2001). Chatrooms as "virtual hangouts" for rural elementary students, Information Technology in Childhood Education Annual, AACE, 105-124.

Morkes, \& Nielson, (1997). Concise, scannable, and objective: How to write for the web. Retrieved June 24, 2003 from http:// www. useit.com/papers/webwriting/ writing.html.

Norshuhada, S., \& Landoni, M. (2002). Evaluation of content activities in children's educational software, International Journal of Evaluation and Program Planning, 25(2), 175-182.
Norshuhada, S., \& Landoni, M. (2003). Children's e-book technology: devices, books and book builder, International Journal of Information Technology in Childhood Education Annual, 105-138.

Norshuhada, S. (2001). Internet instructional method: Effects on students' performance, International Forum of Educational Technology \& Society, 4(3), 72 - 76. Retrieved May 11, 2003, from http://ifets.ieee.org/periodical/ vol_3_2001/v_3_2001.html

Norshuhada, S. (2002). Inovative features of ebooks and e-books builders, $\mathrm{PhD}$ Thesis, University of Strathclyde: Glasgow.

Norshuhada, S., Landoni, M., Gibb, F., \& Shahizan, H. (2003a). E-books technology and its potential applications in distance education, Journal of Digital Information, 3(4), British Computer Society and Oxford University Press. Retrieved Oct 21, 2003, from http:// jodi.ecs.soton.ac.uk/Articles/v03/i04/ Shiratuddin/

Norshuhada, S., Shahizan, H., \& Landoni, M. (2003b). A usability study for promoting eContent in higher education. International Forum of Educational Technology \& Society, 6(4), 112-124.

Rawlins, G. (1991). Technology's impact on the publishing industry over the next decade, Indiana University. Retrieved Oct 24, 2002, from http://archives.obs-us.com/ obs/english/papers/rawlins.htm\#ele2THE NEW.

Schilit, B. (1999) Why e-read? Finding opportunities in the merger of paper and computers. The Future of Print Media, Spring. Retrieved April 20, 2003, from http://www.futureprint. kent.edu/articles/ schilit01.htm. 
Selvidge, P., \& Phillips, C. (2002). E-books: Are we going paperless? Retrieved April 20, 2003, from http://www.usability news.org.

Seniuk, C. (2001). Effects of computers on preschool aged children, Calgary University. Retrieved Oct 15, 2002, from http://www.ucalgary.ca/ dabrent/380/ webproj/cms.html.

Shields, M. K., \& Behram, R. E. (2000). Children and computer technology: Analysis and recommendations, The Future of Children, Children and Computer Technology, 10(2), 4-30.

SHORE. (2000). The effect of screen size on readability using three different portable devices. Retrieved June 25, 2003, from: http://www.otal.umd.edu/SHORE2000/ portadevs/discussion.html.

The United Methodist Publishing House. (2003). Ebooks. Retrieved May 9, 2003, from http://www.cokesbury.com/help/ howto_eBooks.asp.

Thomson Multimedia (2000). Thomson will massproduce next generation rocket ebook, softbook, eBookNet.com. Retrieved June 8, 2000, from http://www.ebooknet.com/ story.jsp?id=1514.

Wilson, R. (2001). Evolution of portable electronic books, Ariadne, 29. Retrieved Oct 10, 2003, from http://www.ariadne.ac.uk/ issue29/wilson/intro.html. 